\title{
Microbial pathogen contamination of waterholes in old Oyo national park: possible wildlife and animal health implications
}

\section{Adetola Taiwo Adetuga ${ }^{a}$, Abosede Olayemi Omonona ${ }^{a}$ and Afusat Jagun Jubril ${ }^{b}$}

a Department of Wildlife and Ecotourism Management, University of Ibadan, Ibadan. Nigeria

b Department of Veterinary Pathology, University of Ibadan, Ibadan. Nigeria

Received: 30/1/2021 Revised: 15/3/2020 Accepted: 22/4/2021


Available online at www.refaad.com

VMPH 2(2); 2021: 49-56

Research Article

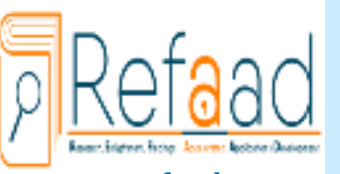

www.refaad.com
Veterinary Medicine and Public Health Journal (VMPH)

Journal Homepage: https://www.refaad.com/views/vmph/home.aspx

ISSN : 2707-7195(Online) 2707-7187(Print)

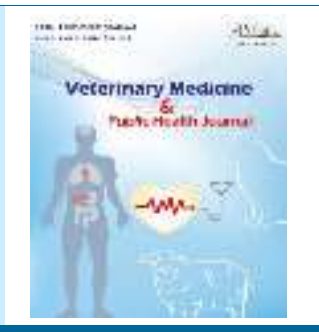

\section{Microbial pathogen contamination of waterholes in old Oyo national park: possible wildlife and animal health implications}

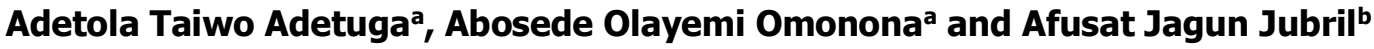

a Department of Wildlife and Ecotourism Management, University of Ibadan, Ibadan. Nigeria

${ }^{b}$ Department of Veterinary Pathology, University of Ibadan, Ibadan. Nigeria

Emails: at.adetuga@gmail.com, ao.omonona@gmail.com, afusatjagun@yahoo.com

* Corresponding author: Adetola Taiwo Adetuga. Email: at.adetuga@gmail.com

How to cite this article: Adetuga AT. et al., Microbial pathogen contamination of waterholes in old Oyo national park: possible wildlife and animal health implications. Veterinary Medicine and Public Health Journal 2(2); 2021: 49-56.

DOI: https://doi.org/10.31559/vmph2021.2.2.4 Received Date: 30/1/2021 Revised Date: 15/3/2021 Accepted Date: 22/4/2021

\section{Abstract}

Surface water quality is an important module of the aquatic ecosystem which is crucial to wildlife and environmental health. The term water quality is sometimes extended to include biodiversity of waters and biological indicators or ecological health. Microbiological examination of water is an essential tool to investigate the presence of microorganisms that might constitute a hazard to both animal and public health. Microbiological examination of waterholes in national parks is thus crucial in assessing ecosystem health. The study therefore aimed at assessing the bacteriological and mycological characteristics of perennial waterholes in Old Oyo National Park (OONP), Nigeria. Coliform test was performed using the most probable number (MPN) technique and heterotrophic plate count (aerobic) by Pour Plate method while fungi count was done using the direct plate and dilution plate methods. Microbial populations were expressed as colony forming units per milliliter (cfu/ml). Different species of microflora were observed in the sampled waterholes includes Bacillus sp, Aspergillus spp, Actinobacter sp, Pseudomonas sp, Penicillium $s p$, Enterobacter $s p$, Klebsiella $s p$, Salmonella $s p$, Flavobacter $s p$, Seratia $s p$ and Shigella $s p$. The presence of Escherichia coli observed in the study is an indication of recent faecal contamination. The mean values of microbial counts of the water samples were higher during the dry season with increased water concentration and more drinking from animals a probable cause. The presence of the various microflora observed in the study could pose a serious threat to both wildlife and public health. The study gave an insight to the health of the animals over seasons in the park and how it can affect health and population and a source of contaminants to all animals. There is need for continuous assessment of water quality in waterholes in OONP as a means of ensuring good ecological health.

Keywords: Microbiological evaluation; Wildlife, Water quality; Old Oyo National Park; Microflora. 


\section{Introduction}

Water is absolutely essential for life sustenance and it is undoubtedly the most precious natural resource that exists on our planet especially for the survival of plants, animals and humans. Most water available for use are always in the form of surface (rivers, streams, lakes) and ground water (Thurman et al. 1998). Although water plays an essential role in maintaining ecological processes that support biodiversity, it is also a medium of transmitting diseases if contaminated (Yakasai et al. 2004). Water is therefore considered to be contaminated if some substances or conditions are present to such a degree that the water cannot be used for a specific purpose (Owa 2013) with the quality is impacted. Hence, water quality is explained in terms of the physical, chemical and biological characteristics of water (Garg et al. 2008). Decrease in water quality due to microbial load threatens the stability, biotic integrity and functionality of aquatic ecosystems. Microbial pathogens that commonly occur in water can be divided into four separate groups. These groups are the viruses, bacteria, pathogenic protozoa and pathogenic helminthes (Igbinosa et al. 2012). Total coliform (TC) and Faecal coliform (FC) have traditionally been regarded as indicators of microbial contamination of waters (Rompre et al. 2002). While E. coli have been reported to be the best indicator bacteria for the assessment of faecal contamination in water (Davies-Colley et al. 2008). Faecal coliform is the bacteria which can be found in the intestines of warm-blooded animals (APHA 1998) and an indicator of disease-causing pathogens in the aquatic environment while total coliform refers to the large collection of different bacteria (Bakobie et al. 2015). The source of contamination by these bacteria is through untreated sewage originating from agricultural land and pastures (Bonetta et al. 2011).

Anthropogenic activities such as effluents and sewage discharges into rivers often stimulate microbial growth and consequently affect water quality. One of the greatest concerns with respect to the quality of water is contamination with pathogenic microorganisms. Microorganisms are normal components of all ecosystems and microbial contamination eliciting from natural or anthropogenic activity is a crucial concern (Bayoumi-Hamuda and Patko 2012). In lieu of this, the presence of microbial pathogens in water poses a considerable health risk to wildlife health. The microbiological examination of water is an essential tool to investigate the presence of microorganisms that might constitute a hazard to both animal and public health. This study therefore examined the bacteriological and mycological characteristics in six selected perennial rivers in Old Oyo National Park, Nigeria.

\section{Methodology}

\section{Study Area:}

The Old Oyo National Park is one of the seven national parks in Nigeria, and has a total land mass area of 2,512 $\mathrm{km}^{2}$ making it the fourth largest national park in Nigeria (Oladeji et al. 2012). It is located between latitudes $8^{0} 15^{\prime}$ and $9^{0} 05^{\circ} \mathrm{N}$ and longitudes $3{ }^{\circ} 35^{`}$ and $4^{0} 42^{\circ} \mathrm{E}$. The park is situated in a transition vegetation zones between mixed deciduous rainforest ecosystem and open savannah woodlands in the north. The annual rainfall varies between $1110 \mathrm{~mm}$ and $1250 \mathrm{~mm}$ while temperature ranges between $20{ }^{\circ} \mathrm{C}$ and $33.6^{\circ} \mathrm{C}$ (Adetoro et al. 2011). The topography of most part of the park is typically low-lying land between 330 and 508 metres above sea level. The park is also abundantly rich in tree species such as Vitellaria paradoxa, Khaya grandifolia, Afzelia africana, Annogeissus leiocarpus, Bligia sapida, Terminalia glycocens, and dominant perennial grass species such as Panicum spp., Ctenium elegans, Andropogon spp., Hyparrhenia spp., Cymbogon giganteus and Beckeropsis unisetus) and fauna species (Kobus kob, Erythrocebus patas, Papio anubis, Crocodilus niloticus, Civettictis civetta. The park is drained by River Tessi in the northern part of the park and River Ogun with its network of tributaries covering the entire southern part of the park.

\section{Sample Site Selection:}

This study was carried out within three of the five ranges of Old Oyo National Park (OONP). The ranges include Oyo-Ile, (located in the northern part of the park), Tede, (located in the southern part of the park) and Marguba (located in the heart of the park). These ranges were purposively selected based on the availability of perennial rivers that were subsequently chosen, the representativeness of the park and the presence of dominant anthropogenic activities by the surrounding local communities such as agriculture, charcoal production, illegal mining and grazing sequel to a thorough reconnaissance survey. 


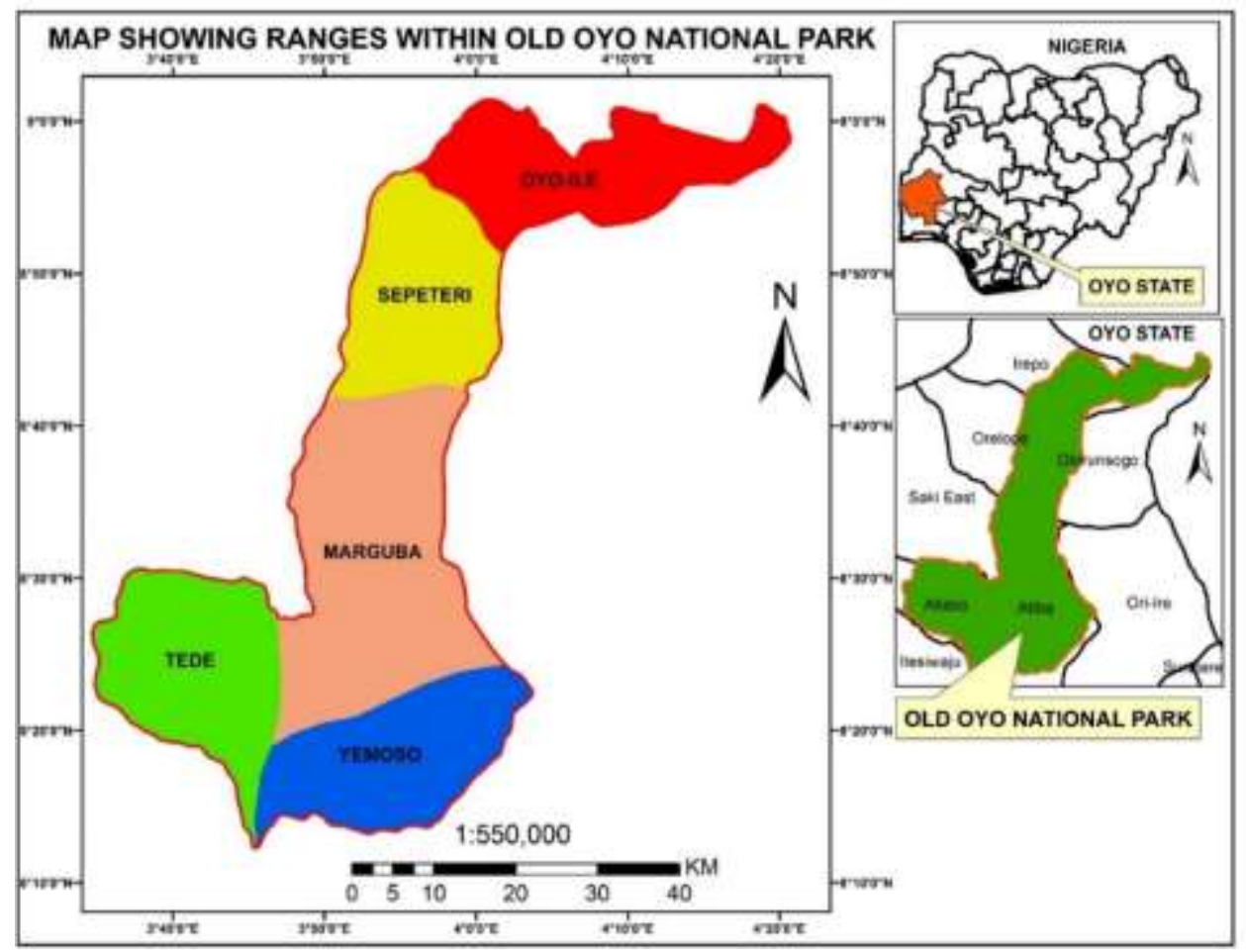

Figure (1): Map of Old Oyo National Park showing the ranges

\section{Sample Collection and Techniques:}

Water samples were collected from six perennial waterholes - River Owu (in Tede range), Rivers Ogun, Oopo, Ayinta (in Marguba range), Rivers Tessi and Sooro (in Oyo-Ile range) using the grab sampling technique into microbiological bottles. Samples' collection was done for four seasons (two wet and two dry) for two consecutive years between January 2017 and April, 2018. The water samples were transported with the aid of an ice-chest box to the Department of Microbiology Laboratory of the University for microbial analysis (bacterial and fungi count).

\section{Laboratory Analysis / Analytical Procedures:}

For the bacteriological analysis of water samples, Coliform test was performed by the most probable number (MPN) technique (Benson, 1998) and heterotrophic plate count (aerobic) by Pour Plate method (Sugita et al. 1993). For identification of total faecal coliform and fungi in water samples, samples were analyzed for the target presumptive bacterial and fungal pathogens using internationally accepted techniques. The fungi were isolated from the water samples by using two methods: The direct plate and the dilution plate, Potato dextrose agar (PDA) and Sabouraud's dextrose agar (SDA) supplemented with chloramphenicol (50 mg/l) and cycloheximide $(500 \mathrm{mg} / \mathrm{l})$ were used for isolation of fungi. Prior to filtration, samples were diluted tenfold with sterile distilled water. About $50 \mathrm{ml}$ of the appropriate dilution of each sample was filtered through a $0.45 \mu \mathrm{m}$ pore size membrane filter, aseptically transferred to Petri dishes containing the appropriate selective media. The isolation of Escherichia coli was carried out using Coli-Chromo agar for $24 \mathrm{~h}$ at $37^{\circ} \mathrm{C}$; while Salmonella and Shigella were isolated on S-S agar for $24 \mathrm{~h}$ at $35^{\circ} \mathrm{C}$. Total coliforms were determined by mENDO agar for $24 \mathrm{~h}$ at $35{ }^{\circ} \mathrm{C}$ and $\mathrm{mFC}$ agar for $24 \mathrm{~h}$ at $44.5{ }^{\circ} \mathrm{C}$, respectively. The estimation of total heterotrophic bacteria, was done on nutrient agar for $48 \mathrm{~h}$ at $37^{\circ} \mathrm{C}$. All colonies with different characteristics on their selective media were identified on the basis of their colonial, morphological and biochemical properties following Bergey's Manual of Determinative Bacteriology (Holt et al. 1994). Bacterial and fungal populations were expressed as colony forming units per milliliter (cfu/ml).

\section{Statistical Analysis:}

Data collected were subjected to descriptive (mean), inferential (ANOVA, T-test) statistics and compared with WHO permissible limits. Post-hoc test (LSD) was used to determine significant differences across the seasons of sampling with statistical significance set at $\alpha_{0.05}$. All the statistical analyses were performed with SPSS software (version 20.0).

\section{Results}

The microbiological characteristics of sampled waterholes in Old Oyo National Park collected for two years (2017 and 2018) are presented in Tables $1-4$. High heterotrophic plate counts were recorded in the study with maximum number of $26.05 \times 10^{5}$ $\mathrm{cfu} / \mathrm{ml}$ recorded in River Ogun in the dry season of 2017. Salmonella / Shigella sp. were observed only during the dry season of 2017 with a maximum count of $58.30 \times 10^{3} \mathrm{cfu} / \mathrm{ml}$ in River Ogun while Staphylococcus aureus was not detected in all the 
waterholes sampled. Furthermore, highest fungi count of $10.00 \times 10^{2} \mathrm{cfu} / \mathrm{ml}$ was observed in River Owu during the dry season of 2017. The total coliform counts observed in the study were discovered to be higher than the WHO permissible limit or guideline for drinking water. Statistically, as shown in Table 5, there were significant differences in the counts of total heterotrophic bacteria, Fungi and total coliforms in the waters sampled $(\mathrm{P}<0.05)$.

Table (1): Microbial Characteristics of selected waterholes in Old Oyo National Park [Dry Season, 2017]

\begin{tabular}{|c|c|c|c|c|c|c|}
\hline $\begin{array}{l}\text { Water } \\
\text { holes }\end{array}$ & $\begin{array}{lr}\text { Total Heterotrophic } \\
\text { bacterial count } \\
\left(\mathrm{x} 10^{5} \mathrm{cfu} / \mathrm{ml}\right)\end{array}$ & $\begin{array}{l}\text { Staphylococc } \\
\text { us aureus } \\
\text { count } \\
\left(\times 10^{2} \mathrm{cfu} / \mathrm{ml}\right)\end{array}$ & $\begin{array}{l}\text { Salmonella/ } \\
\text { Shigella spp } \\
\text { count } \\
\left(\times 10^{3} \mathrm{cfu} / \mathrm{ml}\right)\end{array}$ & $\begin{array}{l}\text { Fungi count } \\
\left(\mathrm{x} 10^{2} \mathrm{cfu} / \mathrm{ml}\right)\end{array}$ & $\begin{array}{l}\text { Total Coliform } \\
\text { count } \\
\left(\mathrm{x} 10^{5} \mathrm{cfu} / \mathrm{ml}\right) / \\
(\mathrm{MPN} / 100 \mathrm{ml})\end{array}$ & $\begin{array}{c}\text { Microflora } \\
\text { Observed }\end{array}$ \\
\hline River Owu & 0.62 & Nil & NG & 10.00 & 3300 & $\begin{array}{c}\text { Bacillus sp., E.coli, Aspergillus flavus, } \\
\text { Penicillium sp. }\end{array}$ \\
\hline River Ogun & 26.05 & Nil & 58.30 & 6.02 & $\geq 160000$ & $\begin{array}{c}\text { Bacillus sp. Shigella sp., E.coli } \\
\text { Pseudomonas sp, Enterobacter sp. } \\
\text { Klebsiella sp, Penicillium sp. }\end{array}$ \\
\hline River Oopo & 5.07 & Nil & 1.50 & 2.00 & 17000 & $\begin{array}{c}\text { Bacillus sp, Shigella sp } \\
\text { Pseudomonas sp,Enterobactersp. } \\
\text { Salmonella sp, Penicillium sp. }\end{array}$ \\
\hline $\begin{array}{l}\text { River } \\
\text { Ayinta }\end{array}$ & 6.41 & Nil & 0.97 & 2.03 & $\geq 160000$ & $\begin{array}{l}\text { Bacillus sp, Shigella sp. } \\
\text { Pseudomonas sp Enterobacter sp } \\
\text { Salmonella sp.Penicillium sp. }\end{array}$ \\
\hline River Tessi & 2.60 & Nil & NG & NG & 50 & Bacillus sp, Seratia sp. \\
\hline River Sooro & 1.84 & $\mathrm{Nil}$ & NG & NG & 4 & Bacillus sp. \\
\hline
\end{tabular}

NG = No growth; Nil = No growth of target organism

Table (2): Microbial Characteristics of selected waterholes in Old Oyo National Park [Wet Season, 2017]

\begin{tabular}{|c|c|c|c|c|c|c|}
\hline $\begin{array}{l}\text { Water } \\
\text { holes }\end{array}$ & $\begin{array}{l}\text { Total } \\
\text { Heterotrophic } \\
\text { bacterial count } \\
\left(\mathrm{x} 10^{5} \mathrm{cfu} / \mathrm{ml}\right)\end{array}$ & $\begin{array}{l}\text { Staphyloc } \\
\text { occus } \\
\text { aureus } \\
\text { count } \\
\left(\times 10^{2} \mathrm{cfu} /\right. \\
\mathrm{ml})\end{array}$ & $\begin{array}{l}\text { Salmonella/ } \\
\text { Shigella spp } \\
\text { count } \\
\left(\times 10^{3} \mathrm{cfu} / \mathrm{ml}\right)\end{array}$ & $\begin{array}{l}\text { Fungi count } \\
\left(\mathrm{x} 10^{2} \mathrm{cfu} / \mathrm{ml}\right)\end{array}$ & $\begin{array}{l}\text { Total Coliform } \\
\text { count } \\
\left(\mathrm{x} 10^{5} \mathrm{cfu} / \mathrm{ml}\right) / \\
(\mathrm{MPN} / 100 \mathrm{ml})\end{array}$ & $\begin{array}{l}\text { Microflora } \\
\text { Observed }\end{array}$ \\
\hline River Owu & 0.1 & 0.00 & 0.00 & 0.00 & 11 & Bacillus sp. Penicillium sp. \\
\hline River Ogun & 3.90 & 0.00 & 0.00 & 0.00 & 900 & $\begin{array}{l}\text { Bacillus sp, Actinobacter sp. } \\
\text { Enterobacter sp. }\end{array}$ \\
\hline River Oopo & 1.00 & 0.00 & 0.00 & 1.00 & 350 & Bacillus sp. Enterobacter sp. \\
\hline River Ayinta & 1.20 & 0.00 & 0.00 & 1.00 & 500 & $\begin{array}{c}\text { Bacillus sp. Shigella sp. } \\
\text { Pseudomonas sp. Salmonella sp. }\end{array}$ \\
\hline River Tessi & 0.40 & 0.00 & 0.00 & 0.00 & 26 & Bacillus sp. \\
\hline River Sooro & 0.60 & 0.00 & 0.00 & 2.00 & 33 & $\begin{array}{c}\text { Bacillus sp. Flavobacter sp. } \\
\text { Enterobactersp. }\end{array}$ \\
\hline
\end{tabular}


Table (3): Microbial Characteristics of selected waterholes in Old Oyo National Park [Dry Season, 2018]

\begin{tabular}{|c|c|c|c|c|c|c|}
\hline $\begin{array}{l}\text { Water } \\
\text { holes }\end{array}$ & $\begin{array}{l}\text { Total } \\
\text { Heterotrophic } \\
\text { bacterial count } \\
\left(\mathrm{x} 10^{5} \mathrm{cfu} / \mathrm{ml}\right)\end{array}$ & $\begin{array}{l}\text { Staphylococc } \\
\text { us aureus } \\
\text { count } \\
\left(\mathrm{x} 10^{2} \mathrm{cfu} / \mathrm{ml}\right)\end{array}$ & $\begin{array}{l}\text { Salmonella/ } \\
\text { Shigella spp } \\
\text { count } \\
\left(\mathrm{x} 10^{3} \mathrm{cfu} / \mathrm{ml}\right)\end{array}$ & $\begin{array}{l}\text { Fungi } \\
\text { count } \\
\left(\mathrm{x} 10^{2} \mathrm{cfu}\right. \\
/ \mathrm{ml})\end{array}$ & $\begin{array}{l}\text { Total Coliform } \\
\text { count } \\
\left(\mathrm{x} 10^{5} \mathrm{cfu} / \mathrm{ml}\right) / \\
(\mathrm{MPN} / 100 \mathrm{ml})\end{array}$ & $\begin{array}{l}\text { Microflora } \\
\text { Observed }\end{array}$ \\
\hline River Owu & 1.6 & Nil & NG & 8.00 & $>1600$ & Bacillus sp., E.coli, Penicillium sp. \\
\hline River Ogun & 0.40 & 0.00 & 0.00 & 0.00 & 540 & Bacillus sp., Enterobacter sp. \\
\hline River Oopo & 2.70 & 0.00 & 0.00 & 0.80 & $>1600$ & $\begin{array}{c}\text { Bacillus sp., Pseudomonas sp., Actinobacteria } \\
\text { sp., Enterobacter sp., Flavobacterium sp., } \\
\text { Aspergillus niger, Penicillium sp. }\end{array}$ \\
\hline River Ayinta & 4.62 & Nil & 0.00 & 1.80 & $\geq 160000$ & $\begin{array}{c}\text { Bacillus sp, Pseudomonas sp., Shigella sp. } \\
\text { Enterobacter sp Salmonella sp. }\end{array}$ \\
\hline River Tessi & 0.40 & 0.00 & 0.00 & 0.10 & $>1600$ & $\begin{array}{c}\text { Bacillus sp., Pseudomonas sp., Actinobacteria } \\
\text { sp., Enterobacter sp., Flavobacterium sp., } \\
\text { Aspergillus niger }\end{array}$ \\
\hline River Sooro & 3.50 & 0.00 & 0.00 & 0.30 & $>1600$ & $\begin{array}{c}\text { Bacillus sp., Pseudomonas sp., } \\
\text { Flavobacterium sp., Aspergillus niger }\end{array}$ \\
\hline
\end{tabular}

$\mathrm{NG}=$ No growth; Nil = No growth of target organism

Table (4): Microbial Characteristics of selected waterholes in Old Oyo National Park [Wet Season, 2018]

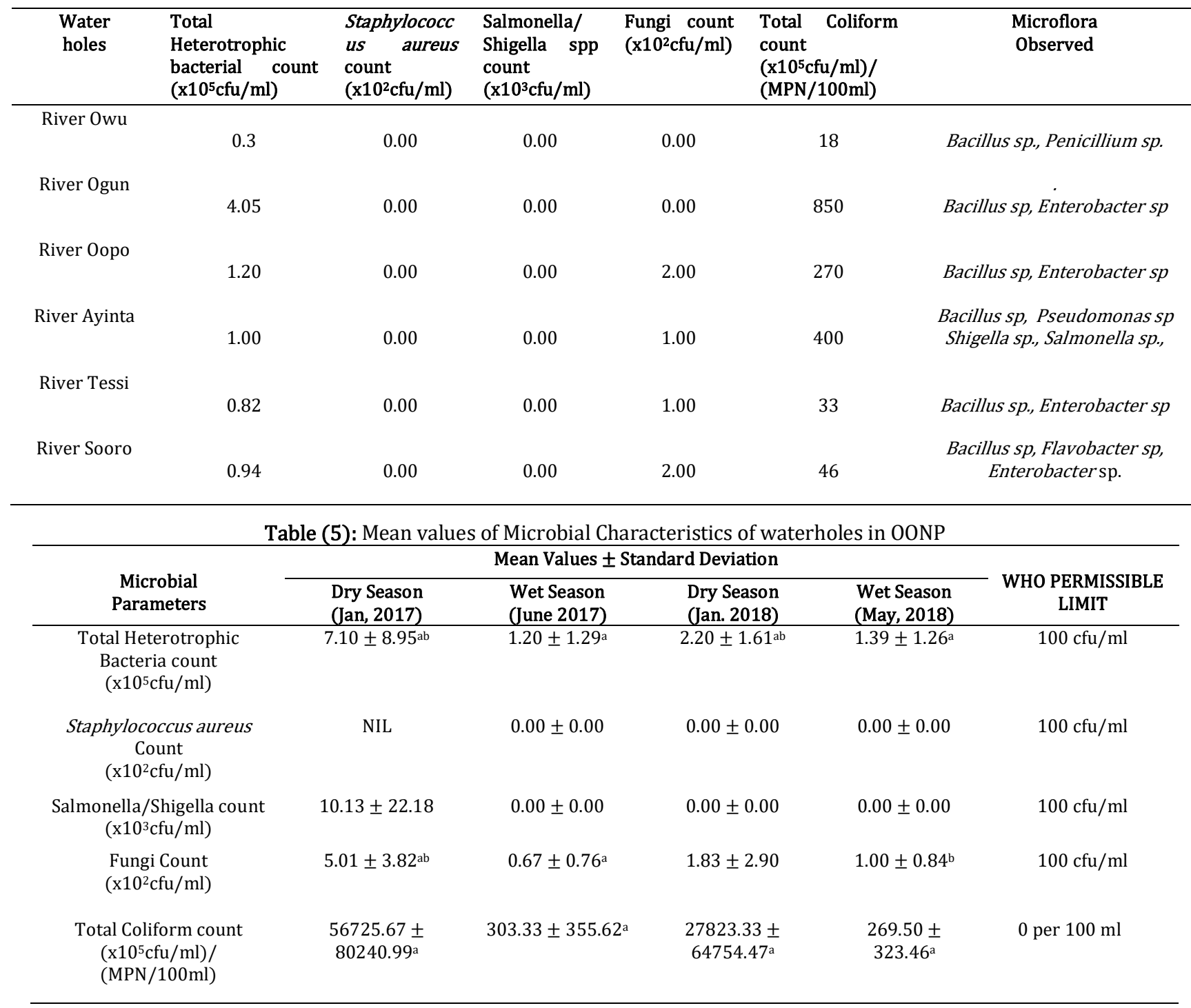

Note: Mean with the same alphabets are significantly different at $\mathrm{P}<0.05$ 


\section{Discussion}

The discharge of contaminated water from domestic, industrial and agricultural sources into water bodies is one of the origins of the degradation of the quality of surface water. In fact, the quality of surface water like rivers rapidly change as a response to alteration within the surrounding environment. Also, water physicochemical parameters, such as $\mathrm{pH}$, nutrients and presence of toxic compounds may influence the density of bacterial populations in surface waters. The assessment of the presence of bacteria and other microbes in water represents a major concern for human- and animal-health protection (Fey et al. 2004). The result showed the total coliform counts observed in the study were discovered to be higher than the WHO permissible limit or guideline for drinking water. The mean values of microbial counts of the water samples were higher during the dry season than the wet season with increased water concentration and more drinking from animals a probable cause. This agrees with the findings of Venkateesharaju et al. (2010) but disagrees with Nnane et al. (2011) who opined that greater incidence of pathogen loads is likely to occur when there is high rainfall. Bacteria have been reported to be ideal markers of microbial pollution of surface waters because of their quick response to environmental changes (Pall et al. 2013) and their distribution depends on changes in water temperature, salinity and physicochemical parameters (Igbinosa et al. 2012).

The total heterotrophic bacteria results from this study exceeded the World Health Organization (WHO) standard for heterotrophic bacteria in potable water and this calls for a great concern. The total heterotrophic bacterial count provides an indication of the general load of aerobic and facultative anaerobic bacteria of a water sample. Its' frequency is commonly used as an indicator of comprehensive microbiological quality (Robertson and Brooks 2003), and their presence in surface water has implications for animal and public health, especially pathogenic organisms. The total heterotrophic bacteria count from this study was found to be highest during the dry season of 2017 and this reflects the contamination extent by the easily decomposable organic matters and also be due to waste disposal into the sampled rivers (Shekha et al. 2013). Interestingly, Staphylococcus aureus, regarded as important indicators of the whole aquatic ecosystem health (Kumar et al. 2010), was not observed in this study while salmonella / shigella (enteric pathogens) were observed in the rivers sampled only during the dry season of 2017 with a mean value of 20.26. This is significant due to the fact that the genus Salmonella have been mostly considered as an endemic public health concern worldwide and its pathogenic potentials (Soto et al. 2006). The sources of contamination are probably due to anthropogenic interferences and animal faeces and the introduction of microorganisms by birds and wild animals possibly during drinking or wallowing (especially during dry season). The high prevalence of Salmonella observed in the study might not be unconnected to manure from freegrazing domestic animals and wild species as corroborated by Negera et al. (2017). The detection of these enteric pathogens from the sampled rivers implies that the surrounding communities of OONP can be put at high risk of diarrhoeal disease when drunk. Also, infection with salmonella (salmonellosis) is one of the most common and important zoonoses, which means it can be transmitted between animals and humans. As such, exposure to infected animal through illegal hunting and consumption of bushmeat may be of serious health concern.

Majority of microbial pathogens are often excreted in faecal matter which contaminates the environment and then gain access to new hosts through ingestion (Toze 1999). Although the indicators of the presence of faecal contamination are many, the favoured faecal indicator (especially in fresh waters including rivers) is the bacterium $E$. coli (Davies-Colley 2013; McBride et al. 2013). The presence of E. coli in River Owu (dry seasons 2017 and 2018) and River Ogun (dry season 2017) indicated recent faecal contamination of the rivers and this could be attributed to animal faecal wastes (wild and livestock) and open defecation. This finding is in consonance with Ajibade et al. (2008) who reported E. coli in the major rivers of Kainji Lake National Park, Nigeria and contrary to Sangodoyin and Opebiyi (2017) who had earlier reported the absence of $E$. coli in some rivers in Old Oyo National Park. E. coli has frequently been reported to be the causative agent of diarrhoea, urinary tract infection, haemorrhagic colitis, and haemolytic uraemic syndrome (Al-Otaibi 2009). In fact, Streptococcus faecalis with E. coli are good indicators of gastrointestinal diseases (Shekha et al. 2013).

The presence of thermo-tolerant coliform bacteria such as Klebsiella $s p$ and Enterobacter $s p$ in River Ogun further confirmed its faecal contamination (WHO, 2017). Though microbes such as Pseudomonas spp, Aspergillus $s p$ and Actinobacter $s p$ observed in the rivers sampled may not appear to represent a health implication, they may be of concern for severely immune-suppressed persons (those with neutrophil counts below 500 per microliter) that drink from them (WHO 2017). Other microbes such as Bacillus sp., Flavobacterium $s p$. and Seratia sp. observed in the waterholes have the tendency to cause disease in vulnerable subpopulations (when they reach infectious load) and to public health especially when these contaminated waterholes are used for recreational and aquatourism activities particularly during the dry season. This necessitates the need to design a holistic wildlife health programs in the park taking cognizance of seasonal influence in the 
contamination of the studied ecosystem from microbial pathogens.

\section{Conclusion}

Water quality in aquatic systems is significant because it maintains the ecological processes that support biological diversity. The presence of microbial pathogens in water poses a considerable health risk to animal and human health. The bacteriological and mycological analyses of the water samples from this study further confirmed that the water from the sampled waterholes is unsafe for consumption as coliform counts were above the permissible limits recommended by WHO. Meeting water quality expectations of rivers in Old Oyo National Park is important and required to protect drinking water resources, encourage recreational activities and provide a good enabling environment for fish and wildlife. Microbiological evaluation of waterholes in Old Oyo National Park is very necessary to assess potential microbial exposure while their knowledge is very crucial to the health of aquatic species while forestalling any disease outbreak.

Acknowledgement: The authors are grateful and appreciate the critical evaluations of the anonymous reviewers.

Conflict of Interest: The authors have not declared any conflict of interests.

\section{References}

1. Adetoro, A. O., Oyeleye, D. O. \& Ijeomah, H. M. (2011). Causes and impacts of conflicts on biodiversity management at the Buffer zone of Old Oyo National Park, Oyo State, African Research Review 5 (1):485 491, https://doi.org/10.4314/afrrev.v5i1.64546.

2. Ajibade, W. A., Ayodele, I. A. \& Agbede, S. A. (2008). Water quality parameters in the major rivers of Kainji Lake National Park, Nigeria. African Journal of Environmental Science and Technology Vol. 2 (7), pp. 185-196.

3. Al-Otaibi, E. L. (2009). Bacteriological assessment of urban water resources in Khamis Mushait governorate, southwestern Saudi Arabia. Inter J Health Geographics. 8(1):16, https://doi.org/10.1186/1476-072x-8-16.

4. APHA. (1998). Standard methods of water and waste water analysis. Washington D.C: American Public HealthAssociation

5. Bakobie, N., Sukairazu, I. \& Duwiejuah, A. B. (2015). Assessment of dam water quality in three selected communities in Savelugu-Nanton Municipality, Ghana. Int. Res. J. Public Environ. Health Vol 2(12): 225-231.

6. Bayoumi-Hamuda, H. E. A. F. \& Patko, I. (2012). Ecological monitoring of Danube water quality in Budapest region. Am J Environ Sci 8(3): 202-211, https://doi.org/10.3844/ajessp.2012.202.211.
7. Benson, H. J. (1998). Microbiological applications: Laboratory manual in general Microbiology, seventh edition, pp. 208-211

8. Bonetta, S., Borelli, E., Bonetta, S., Conio, O., Palumbo, F. \& Carraro, E. (2011). Development of a PCR protocol for the detection of Escherichia coli 0157:H7 and Salmonella spp. in surface water. Environ Monit Assess. 177: 493-503.

9. Davies-Colley, R. J. (2013). River water quality in New Zealand: an introduction and overview. In Dymond JR ed. Ecosystem services in New Zealand conditions and trends. Manaaki Whenua Press, Lincoln, New Zealand.

10. Davies-Colley, R. J., Nagels, J. W. \& Lydiard, E. (2008). Faecal bacterial dynamics and yields from an intensively dairy-farmed catchment. Water Science and Technology, 57(10): 1519-1523, https://doi.org/10.2166/wst.2008.257.

11. Fey, A., Eichler, S., Flavier, S., Christen, R., Hofle, M. G. \& Guzman, C. A. (2004). Establishment of a real-time PCR-based approach for accurate quantification of bacterial RNA targets in water, using Salmonella as a model organism. Appl Environ Microbiol 70(6): 3618-3623, https://doi.org/10.1128/aem.70.6.36183623.2004

12. Garg, D., Kaur, R., Chand, D., Mehla, S. K. \& Singh, R. V. (2008). Analysis of Water Quality of Bharatpur Area in Post-Monsoon Season, January 2007. Rasayan J. Chem. 1(4): 743-750.

13. Holt, J. G., Krieg, N. R., Senath, P. H. A., Staley, J. T. \& Williams, S. T. (1994). Bergey's Manual of Determinative Bacteriology. Ninth Edition. Baltimore Md., Willaims and Wilkins.

14. Igbinosa E. O., Uyi O. O., Odjadjare E. E., Ajuzie C. U., Orhue P. 0. \& Adewole E. M. (2012). Assessment of physicochemical qualities, heavy metal concentrations and bacterial pathogens in Shanomi Creek in the Niger Delta, Nigeria. African Journal of Environmental Science and Technology, 6(11):419424, https://doi.org/10.5897/ajest12.038.

15. Kumar, A., Bisht, B. S., Joshi, V. D., Singh, A. K. \& Talwer, A. (2010). Physical, chemical and bacteriological study of water from river of Uttarakhand. J. Human Ecol, 32(3): 169- 173, https://doi.org/10.1080/09709274.2010.11906336.

16. McBride, G. B., Davies-Colley, R. J. \& Bargh, M. (2013). Toward a nationally consistent and dependable surface freshwater monitoring programme for New Zealand. Description and costs including quality assurance. NIWAClient Report HAM2013-024. 41 p.

17. Negera, E., Nuro, G. \& Kebede, M. (2017). Microbiological assessment of drinking water with reference to diarrheagenic bacterial pathogens in Shashemane Rural District, Ethiopia. African Journal of Microbiology Research, 11 (6): 254-263, https://doi.org/10.5897/ajmr2016.8362.

18. Nnane, D. E., Ebdon, J. E. \& Taylor, H. D. (2011) Integrated analysis of water quality parameters for cost-effective faecal pollution management in river catchments. Water Research, 45(6): 2235-2246, https://doi.org/10.1016/j.watres.2011.01.018.

19. Oladeji, S. O, Agbelusi E, A \& Ajiboye, A. S. (2012). Assessment of Aesthetic Values of Old Oyo National 
Park. American Journal of Tourism Management, 1(3): 69-77, https://doi.org/10.5923/j.tourism.20120103.02.

20. Owa, F. D. (2013). Water Pollution: Sources, Effects, Control and Management. Mediterranean Journal of Social Sciences, 4(8), https://doi.org/10.5901/mjss.2013.v4n8p65.

21. Pall, E., Niculae, M., Kiss, T., Sandru, C. D. \& Spinu, M. (2013). Human impact on the microbiological water quality of the rivers. Journal of Medical Microbiology 62(11): 1635-1640, https://doi.org/10.1099/jmm.0.055749-0.

22. Rompre, A., Servias, P., Baudart, J., de-Roubin, M. \& Laurent, P. (2002). Detection and enumeration of coliforms in drinking water. Current methods and emerging approaches. J. Microbiol Methods, 49(1):31-54, https://doi.org/10.1016/s01677012(01)00351-7.

23. Sangodoyin, A. Y. \& Opebiyi, E. O. (2017). Assessment and Management of the Effects of Illegal Grazing on River Water Quality in Old Oyo National Park, Nigeria. Indian Journal of Ecology, 44(2): 300-303.

24. Shekha, Y. A., Ismael, H. M. \& Ahmed, A. A. (2013). Bacteriological and Mycological Assessment for Water Quality of Duhok Reservoir, Iraq. Jordan Journal of Biological Sciences 6(4): 308 - 315, https://doi.org/10.12816/0001630.

25. Soto, S. M., Rodriguez, I., Rodicio, M. R., Vila, J. \& Mendoza, M. C. (2006). Detection of virulence determinants in clinical strains of Salmonella enterica serovar Enteritidis and mapping on macrorestriction profiles. J Med Microbiol, 55(4): 365-373, https://doi.org/10.1099/jmm.0.46257-0.

26. Sugita, H., Okamoto, N. \& Nakamura, T. (1993). Characterization of microaerophilic bacteria isolated from the coasted waters of Tokyo Bay, Japan. FEMS Microbiol Ecol., $13(1)$ : 37-46, https://doi.org/10.1111/j.1574-6941.1993.tb00049.x.

27. Thurman, R., Faulkner, B., Veal, D., Cramer, G. \& Meikle-John, M. (1998). Water Quality in Rural Australia. J Appl Microbiol, 84:627-632

28. Toze, S. (1999). PCR and the detection of microbial pathogens in water and wastewater. Wat. Res. 33(17): 3545-3556, https://doi.org/10.1016/s0043-1354(99)00071-8.

29. Venkatesharaju, K., Ravikumar, P., Somashekar, R. K. \& Prakash, K. L. (2010). Physicochemical and bacteriological investigation on the river Cauvery of Kollegal stretch in Karnataka. Kathmandu University J Sci, Eng Technol., 6(1): 50- 59, https://doi.org/10.3126/kuset.v6i1.3310.

30. World Health Organization (WHO) (2017). Guidelines for Drinking-water Quality. Fourth Edition Incorporating the First Addendum. Pp 1-631

31. Yakasai, I. A., Salawu, F. \& Musa, H. (2004). The concentration of lead in Ahmadu Bello University Dam, Raw, Treated (tap) and ABUCONS Pure Waters. Chem Class Journal. 1:86-90 